\title{
The growth of Mycobacterium leprae in nude mice
}

\author{
S CHEHL, * J RUBY, $\dagger$ C K JOB $\ddagger \&$ R C HASTINGS \\ * Pharmacology Research Department, National Hansen's Disease \\ Center, Carville, Louisiana 70721 USA; $\dagger$ Louisiana State Univer- \\ sity Dental School, New Orleans, LA 70119, USA; $¥$ Pathology \\ Research Department, National Hansen's Disease Center, Carville, \\ LA 70721, USA; § Laboratory Research Branch, National Hansen's \\ Disease Center, Carville, LA 70721, USA
}

Accepted for publication 25 May 1983

\begin{abstract}
Summary Armadillo-derived Mycobacterium leprae were inoculated in graded doses into the left hind foot-pads of $160 \mathrm{nu} / \mathrm{nu}$ mice and the same number of $\mathrm{BALB} / \mathrm{c}$ mice. The course of the infection was followed for 18 months. The nu/nu mice developed massive foot-pad enlargements with eventual dissemination of the bacilli in virtually all organs outside the central nervous system. The acid-fast bacilli were identified as $M$. leprae. BALB/c mice showed a characteristic localized infection. In the nu/nu mice, bacilli were found in large numbers free in the cytoplasm of striated muscle cells and in macrophages, both free in the cytoplasm and within phagosomes. With time, the $M$. leprae in the nu/nu mice showed a tendency to stain more and more non-solidly, suggesting that death of $M$. leprae occurs in these animals despite their lack of the capacity to develop cell-mediated immunity. This model of disseminated leprosy seems useful for a number of studies of the disease.
\end{abstract}

Athymic, nude mice have been used in leprosy research since 1976. It has been independently demonstrated ${ }^{1,2}$ (also Nakamura \& Yogi, private communication) that these animals would support the growth of large numbers of Mycobacterium leprae. The present report concerns details of the growth of armadillo-derived $M$. leprae in nude mice at Carville. These findings have been reported in preliminary form in $1980 .{ }^{3,4}$ 


\section{Materials and methods}

\section{HUSBANDRY}

Specific pathogen-free (defined flora) nude mice [(BALB/c An Bom) nu/nu DF], 4-5 weeks' old, were transported by air under sterile conditions from HarlanSprague-Dawley, Madison, Wisconsin. Upon arrival these animals were transferred to sterile cages and maintained in a laminar flow animal isolator unit (Model 600, Contamination Control, Inc., Culpsville, PA) situated in a temperature $\left(78-80^{\circ} \mathrm{F}\right)$ and humidity $(45-55 \%)$ controlled room. The laminar flow unit was connected to an emergency generator which was activated within $3 \mathrm{~s}$ of an interruption in the electric supply. The animals were provided with sterilized autoclavable rodent food (Service Feed Co., Baton Rouge, LA) and water ad libitum. Cages (autoclavable cages, Lab Products, Rochelle Park, NJ), bedding, food and water changes were made twice weekly under aseptic conditions.

Weekly bacteriological monitorings of air flow from the laminar flow isolator, water bottles after use, faeces and urine were made. The cleanliness of the physical facility and laminar flow unit were aggressively maintained.

The counterpart, BALB/c female mice used as controls in this experiment (Tempco Breeding Labs, Houston, TX), were maintained in a conventional environment; food and water were provided as needed; cages, bedding and water bottles were changed twice weekly. Specimens of feed, water, faeces and bedding were monitored monthly for pathogenic bacterial growth on trypticase soy agar.

\section{INOCULUM AND INOCULATION}

A suspension of Mycobacterium leprae was prepared at $4{ }^{\circ} \mathrm{C}$ (on an ice bed) using aseptic technique from the spleen tissue of an experimentally infected armadillo as per the methodology of Prabhakaran et al.,$^{5}$ with slight modifications. The suspension thus obtained (Morphological Index $=10$ ) was tested for sterility in thioglycolate at $37^{\circ} \mathrm{C}$ for $24 \mathrm{~h}$ and was subsequently diluted in Hank's balanced salt solution to contain $1 \times 10^{6}, 1 \times 10^{5}, 1 \times 10^{4}$ bacilli per $30 \mu$ l. One hundred and sixty nu/nu mice and an equal number of control BALB/c mice were inoculated in the plantar surface of the left hind foot-pad (LHF). Sixty nu/nu and 60 BALB/c mice received $1 \times 10^{6} \mathrm{M}$. leprae, 50 from each group received $1 \times 10^{5}$, and 50 received $1 \times 10^{4} M$. leprae. The animals were housed 10 per cage.

\section{HAR VESTS}

The experimental $(\mathrm{nu} / \mathrm{nu})$ and the control $(\mathrm{BALB} / \mathrm{c})$ mice were harvested at 5 days (for baseline), and at 90, 180, 272, 365 and 565 days after inoculation. Six to seven mice from the $1 \times 10^{6}$ inoculum groups and 5-6 mice from each of the other groups were sacrificed at each harvest. 


\section{HISTOPATHOLOGICAL STUDIES}

At each harvest one animal from each of the $1 \times 10^{6}$ inoculum groups of $\mathrm{nu} / \mathrm{nu}$ and BALB/c mice was autopsied and various organs and tissues were individually weighed and prepared for histopathological studies. The tissues were immediately fixed in $10 \%$ buffered formalin and processed for paraffin sections. Five micron sections were cut and stained with haematoxylin and eosin and a modified Fite-Faraco stain for M. leprae.

\section{ELECTRON MICROSCOPIC STUDY}

A foot-pad of a nude mouse which had been inoculated 217 days before with $1 \times 10^{8} \mathrm{M}$. leprae from nude mouse foot-pad passage was cut into approximately 1 $\mathrm{mm}$ cubes and fixed in $5 \%$ glutaraldehyde solution at $4{ }^{\circ} \mathrm{C}$ for $3 \mathrm{~h}$. After fixation, the tissue was repeatedly rinsed in several changes of cacodylate buffer containing $0 \cdot 2 \mathrm{M}$ sucrose for a minimum of $24 \mathrm{~h}$, dehydrated in a graded series of ethanol, immersed in either propylene oxide or dimethylsulphoxide and embedded in pure Spurr's resin. One micron sections were first prepared and stained with $1 \%$ toluidine blue for orientation of the tissue. Ultra-thin sections were made from suitable blocks using a Reichert OM-02 ultramicrotome, placed in uncoated grids, stained with uranyl acetate and lead citrate and studied using a Philips EM 300 electron microscope.

\section{BACTERIAL ENUMERATIONS}

\section{Foot-pads}

In the 5-6 animals from each group remaining after the histopathologic study, a routine harvesting of the inoculated hind foot-pad (LHF) and the contralateral hind foot-pad (RHF) was performed by standard techniques. ${ }^{6,7}$ The technique was slightly modified to process the very large sized foot-pads of the 365- and 565 -day harvests. The specimens were individually weighed and stored at $-80^{\circ} \mathrm{C}$ (Kelvinator series 5000, Commercial Products, Inc., Maintowe, WI) until processing.

\section{Liver-spleen}

Liver-spleen pools (LS) from each animal were removed, weighed and stored at $-80^{\circ} \mathrm{C}$ until use. They were removed from the freezer, immersed briefly (10-15 s) in liquid nitrogen and homogenized for $2 \mathrm{~min}$ in a micro-attachment of a heavy duty Waring blender using normal saline to make a $20 \% \mathrm{w} / \mathrm{v}$ suspension. The LS homogenate was then sonicated for 15-20 s at $50 \mathrm{~W}$ (Sonifier Cell Disrupter Model W-185, Heat Systems Ultrasonics, Inc., Plainview, NY). A 1:10 dilution 
was made in normal saline and slides were prepared for enumeration by standard acid-fast staining techniques.

\section{Carcass}

The carcasses remaining after the removal of the hind foot-pads and liver-spleen, were weighed and stored at $-80^{\circ} \mathrm{C}$ until homogenization. The carcasses were removed from the freezer, immersed in liquid nitrogen for 30-50 s and shattered in a Waring blender. Normal saline was then added to make a $20 \% \mathrm{w} / \mathrm{v}$ suspension and the carcass was homogenized for $3 \mathrm{~min}$. The resulting homogenate was sonicated for 20-25 s at $50 \mathrm{~W}$, and filtered through a single layer of gauze. The filtrate was diluted 1:10 with normal saline and slides were prepared for bacterial enumeration by standard acid-fast staining techniques.

\section{IDENTIFICATION TESTS OF M. LEPRAE}

Various tests for the identification of $M$. leprae were performed to determine the authenticity of the acid-fast bacilli obtained from the nu/nu, inoculated foot-pads (LHF) at the 365- and 565-day harvests.

\section{Growth pattern in $B A L B / c$ mice}

An aseptically prepared $M$. leprae suspension from the inoculated nu/nu foot-pad tissue of the 365-day harvest, was diluted in Hank's balanced salt solution to contain $5 \times 10^{3}$ bacilli per $30 \mu \mathrm{l}$. Ninety BALB/c mice were inoculated in the plantar surface of the left hind foot with $5 \times 10^{3} \mathrm{M}$. leprae. The inoculated foot-pads were individually harvested and enumerated at 90, 120, 150, 180, 272 and 365 days after inoculation. Six animals were sacrificed at each interval.

\section{Dopa oxidase and pyridine extraction}

The AFB suspensions from the infected nu/nu footpads at 364 and 565 days after inoculation were tested for DOPA oxidase activity ${ }^{8}$ and the pyridine extraction test. ${ }^{9}$

In vitro cultivability

The AFB suspensions from the 180-, 272-, 363- and 565-day harvests were inoculated into Lowenstein Jensen slants, Middlebrook 7H9 liquid medium and Dubos liquid medium, incubated at room temperature $\left(23-25^{\circ} \mathrm{C}\right), 33^{\circ} \mathrm{C}$ and $37^{\circ} \mathrm{C}$, and observed for $6-8$ weeks. 


\section{Lymphocyte blast transformation ( LBT)}

Dharmendra antigen was prepared from the acid-fast bacilli (AFB) derived from the experimentally infected $\mathrm{nu} / \mathrm{nu}$ foot-pad tissue and armadillo lymph nodes using the methodology of Dharmendra with slight modifications. ${ }^{10}$ The comparative LBT activity of these antigens was studied in 6-day mononuclear cell cultures prepared from peripheral blood of lepromin-positive normal human subjects and from lepromin-negative leprosy patients. The methods have been previously described" with minor modifications. Dharmendra antigen was used to the concentration of $5 \mu \mathrm{g} /$ well and the medium was supplemented with $10 \% \mathrm{v} / \mathrm{v}$ autologous plasma instead of $20 \% \mathrm{v} / \mathrm{v}$ AB serum.

\section{Results}

\section{SUR VIVAL}

Based on spontaneous deaths, the survival of nude mice maintained under sterile, laminar flow housing conditions was satisfactory and approached that of the conventionally housed, immunologically competent BALB/c mice (Figure 1).

\section{WEIGHTS}

The inoculated foot-pads of the nude mice became erythematous and began to

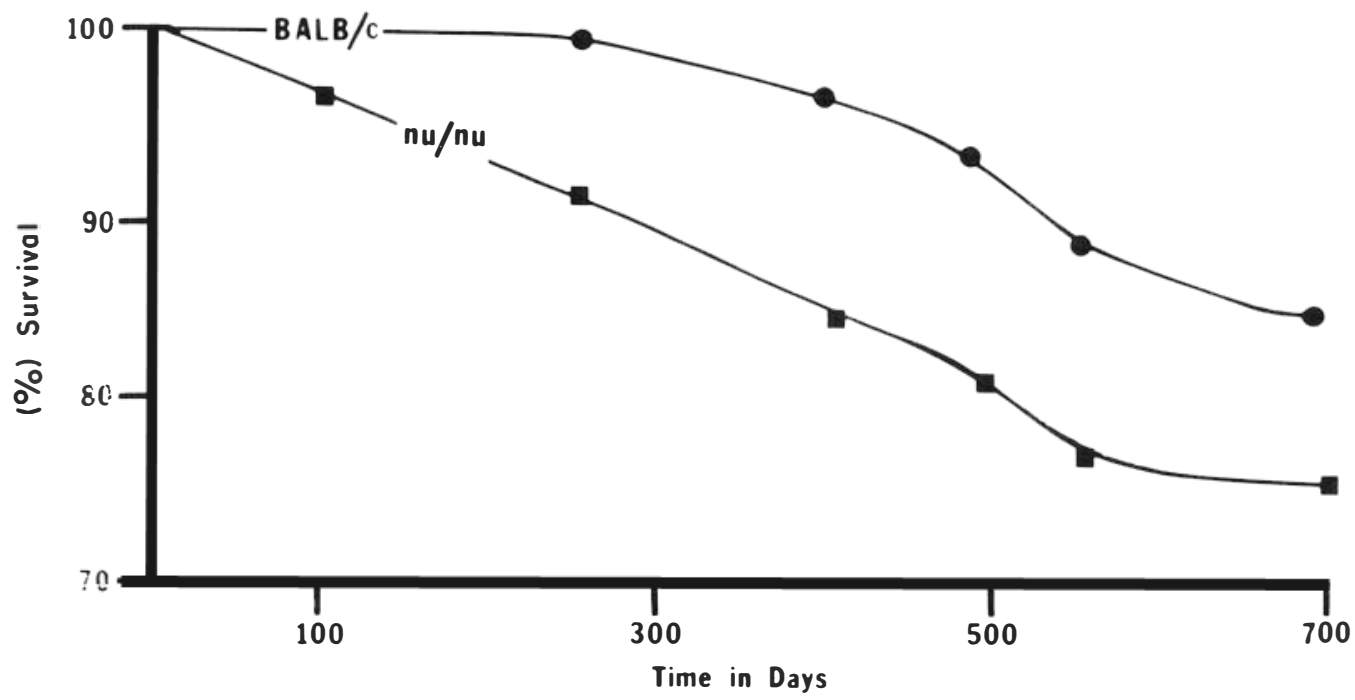

Figure 1. The survival of nu/nu mice housed under sterile laminar flow conditions compared to the survival of conventionally housed $\mathrm{BALB} / \mathrm{c}$ mice. 


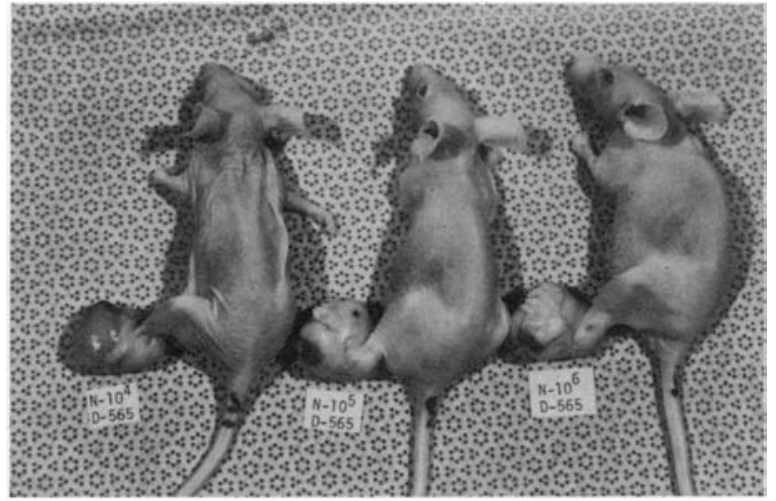

Figure 2. Enlargement of inoculated foot-pads of nu/nu mice 565 days after inoculation with Mycobacterium leprae.

enlarge by 272 days after inoculation. There was a progressive enlargement of the inoculated foot-pads and they reached massive proportions by the 565-day harvest (Figure 2). The control BALB/c mice showed no foot-pad enlargement. The weights of the inoculated foot-pads at different time intervals are shown in Figure 3. The weights of the liver-spleen pools are given in Figure 4. There were no noteworthy changes in the body weights of either the nude mice or the BALB/c mice.

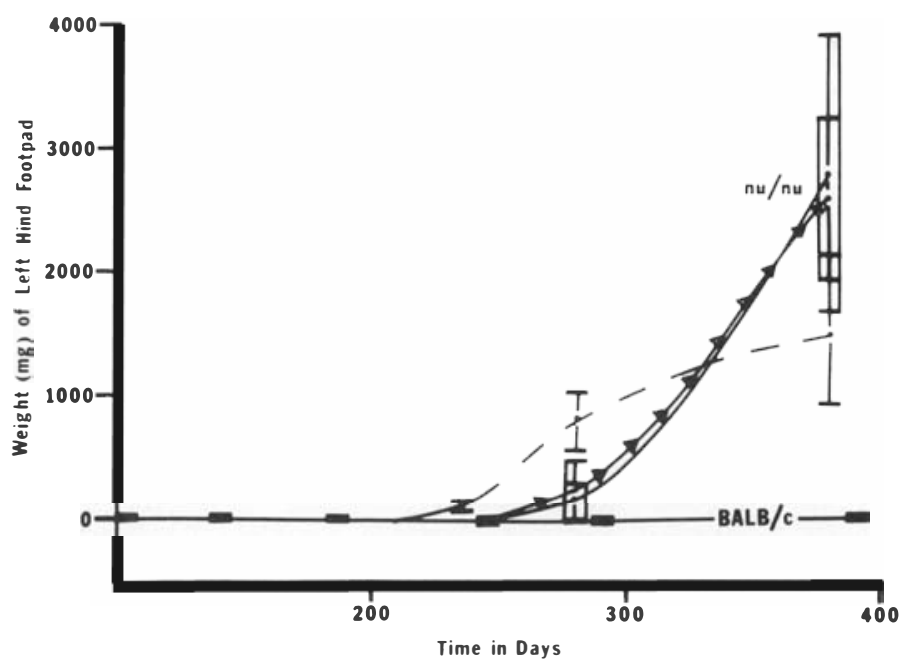

Figure 3. Weights of inoculated foot-pads of nu/nu mice inoculated with $1 \times 10^{4}(--), 1 \times 10^{5}$ $(\longrightarrow), 1 \times 10^{6}(\longrightarrow)$, and BALB/c mice inoculated with $1 \times 10^{4}(\square-\square), 1 \times 10^{5}(\square-\square)$ and $1 \times 10^{6}$ (- Mycobacterium leprae. Values are depicted as means $\pm \mathrm{SD}, \mathrm{N}=6$. 


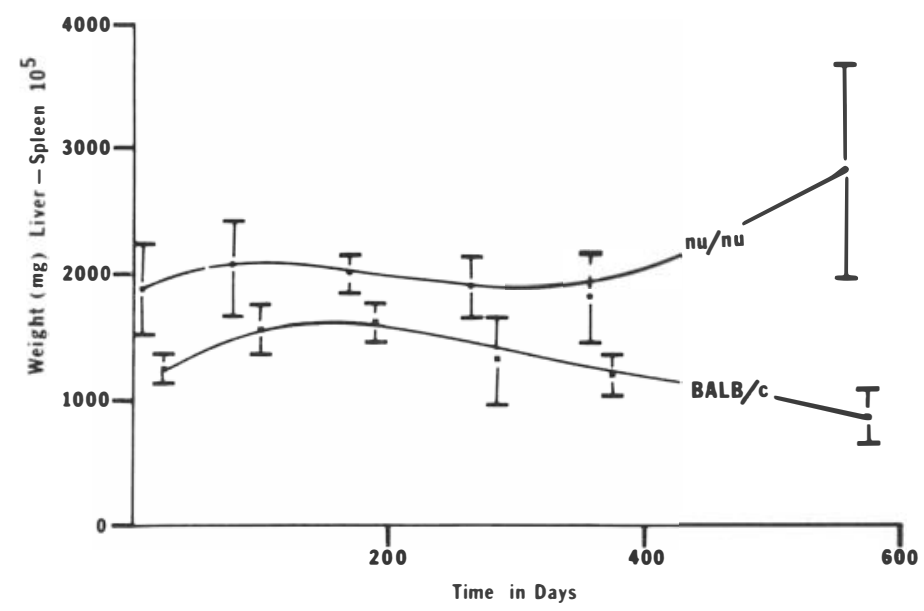

Figure 4. Weights of livers and spleens (combined) in $\mathrm{nu} / \mathrm{nu}$ and BALB/c mice inoculated with $1 \times 10^{5}$ Mycobacterium leprae. Values are depicted as means $\pm \mathrm{SD}, \mathrm{N}=6$.

\section{BACTERIAL ENUMERATIONS}

The results of bacterial enumerations from the inoculated left hind foot-pads (LHF), showing numbers of bacilli per foot-pad at various intervals, are given in Figure 5. The average level of AFB in the inoculated foot-pads in nude mice reached over $5 \times 10^{10}$ bacilli per foot-pad, while the BALB/c mice exhibited their characteristic limited growth pattern and plateaus. The dissemination to the contralateral, uninoculated foot-pad (RHF) was seen at a rather surprisingly late stage of the infection in the nude mice (Figure 6).

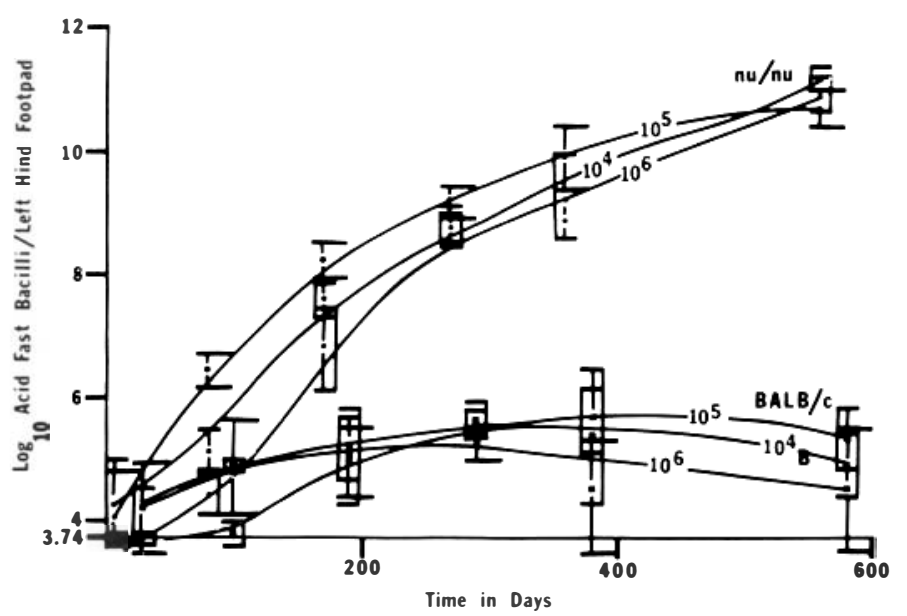

Figure 5. Acid-fast bacilli harvested from the inoculated foot-pads of nu/nu and BALB/c mice after inoculation with $1 \times 10^{4}, 1 \times 10^{5}$ and $1 \times 10^{6}$ Mycobacterium leprae. Values are depicted as means $\pm \mathrm{SD}, \mathrm{N}=6$. 


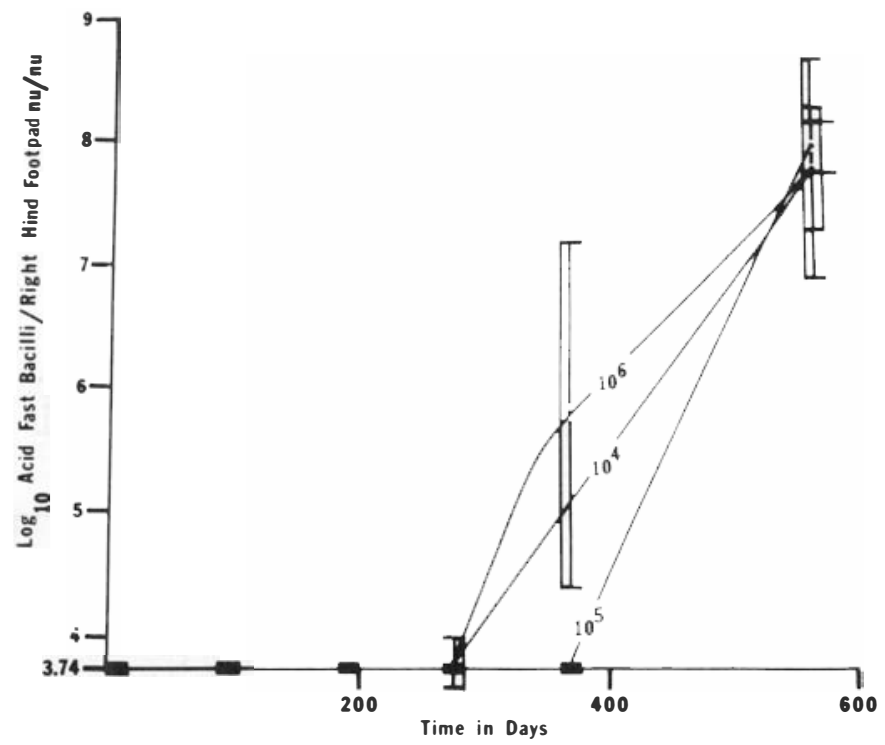

Figure 6. Acid-fast bacilli harvested from the contralateral, uninoculated hind foot-pads of nu/nu mice after inoculation with Mycobacterium leprae. No acid-fast bacilli were detected in the contralateral, uninoculated hind foot-pads of BALB/c mice. Values are depicted as means $\pm S D$, $\mathrm{N}=6$.

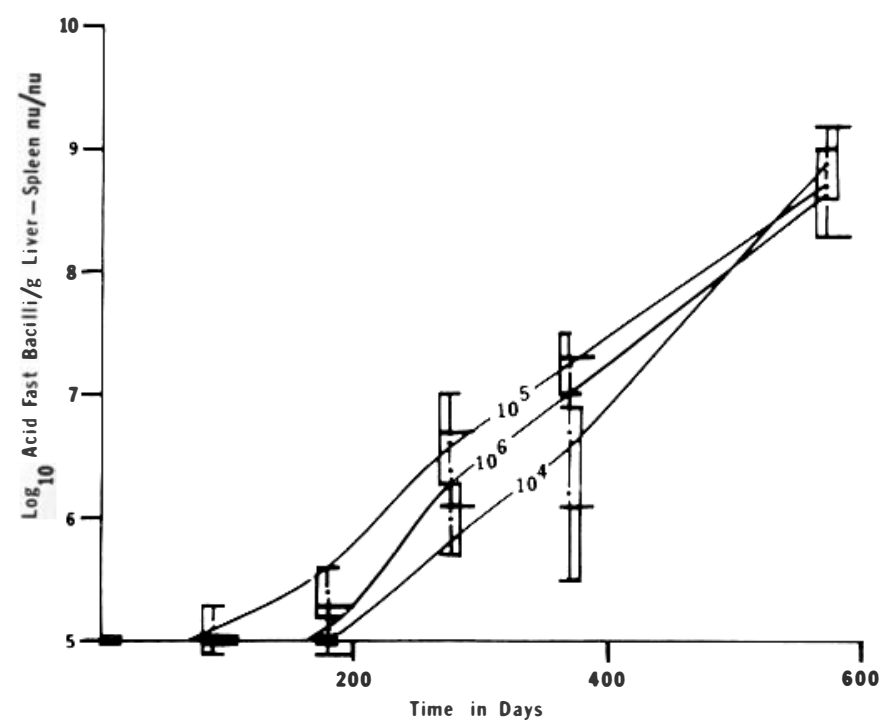

Figure 7. The concentration of acid-fast bacilli per gram of tissue in the liver-spleen pools of nu/nu mice inoculated with Mycobacterium leprae. Values are depicted as means $\pm \mathrm{SD}, \mathrm{N}=6$. 


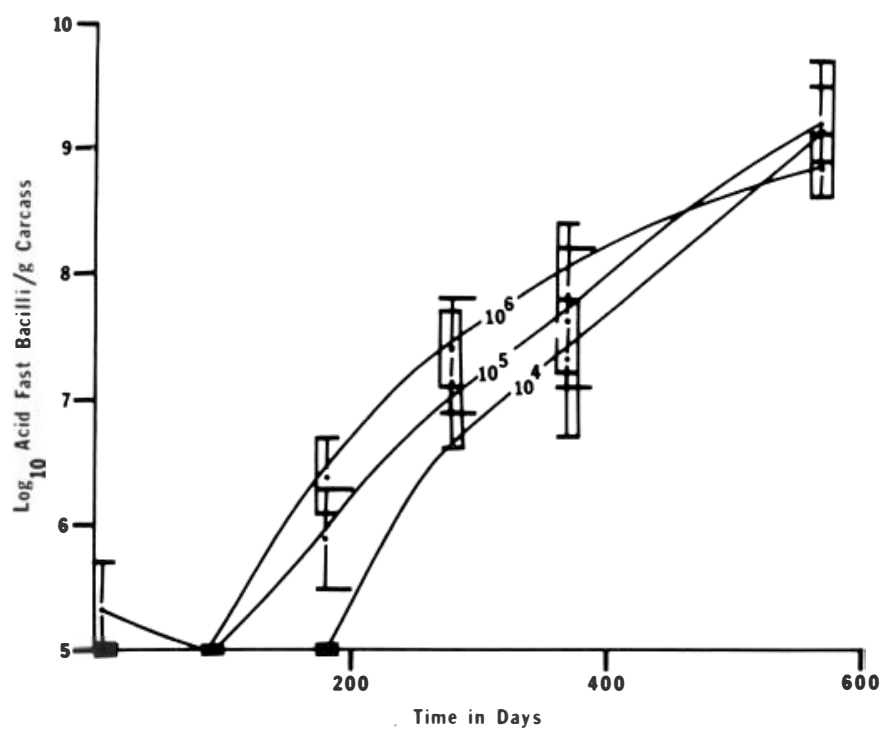

Figure 8. The concentration of acid-fast bacilli per gram of tissue in the carcasses of nu/nu mice inoculated with Mycobacterium leprae. Values are depicted as means $\pm \mathrm{SD}, \mathrm{N}=6$.

Expressed as concentrations of AFB per gram of tissue in the LHF, the ultimate mycobacteriosis of approximately $1-5 \times 10^{10} \mathrm{AFB} / \mathrm{g}$ is reached in the nude mice by 272 days after inoculation in all 3 groups. Thereafter, the increase in numbers of AFB is accommodated by enlargement of the foot-pads. The contrasting, characteristic plateaus were reached at approximately $3-4 \log$ s lower concentrations in the BALB/c foot-pads.

Figure 7 shows the AFB per gram of tissue in liver-spleen pools at given stages of infection. A dissemination to the liver-spleen in nude mice occurred by 180 days after inoculation and the AFB concentration approached $1 \times 10^{9}$ bacilli per gram by the 565 -day harvest. Figure 8 presents similar dissemination and concentrations of bacilli in nude carcasses remaining after removal of hind foot-pads and liver-spleens. A trend towards a continued increase in AFB per gram is seen in both the liver-spleen pools and carcasses of all groups of nude mice at the time of the termination of the experiment. The final concentration was slightly higher in the carcasses than that in liver-spleen tissues. No dissemination was observed in the BALB/c mice.

\section{MORPHOLOGICAL INDEXES}

Figure 9 shows Morphological Indexes which include LHF, liver-spleen pools, and carcasses of nude mice. Interestingly the Morphological Index falls with time in both the inoculated and the contralateral uninoculated foot-pads and in the carcasses of the nude mice. The Morphological Index is highest in AFB from the liver-spleen pool at the time of the final harvest. 


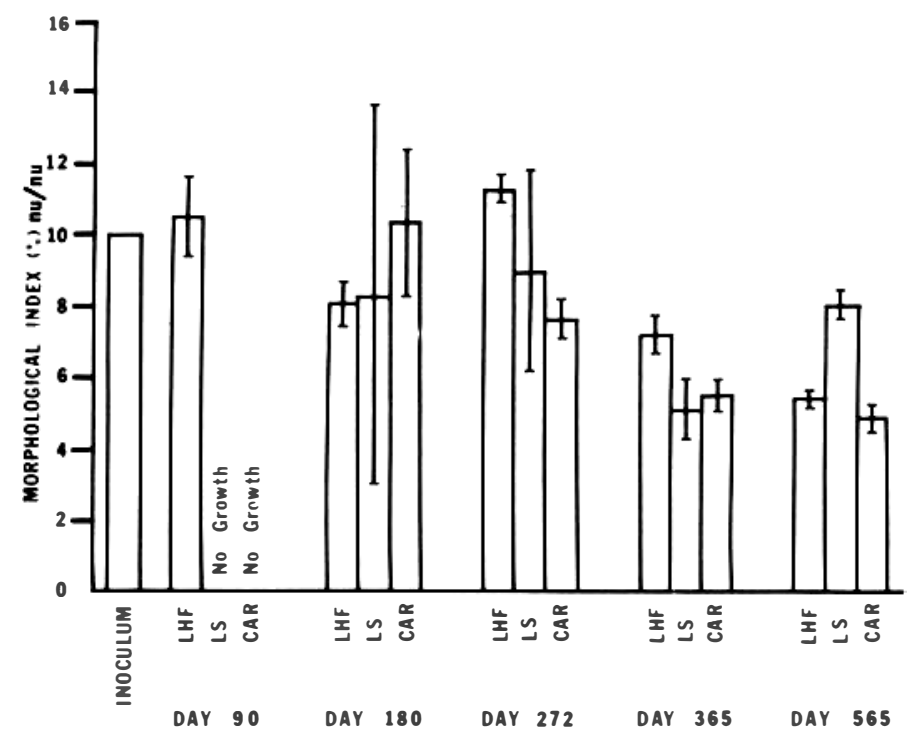

Figure 9. Percentage of solidly staining acid-fast bacilli (Morphological Index) in the various tissues of nu/nu mice after inoculation with Mycobacterium leprae. Values are depicted as means \pm SEM, $\mathrm{N}=6$.

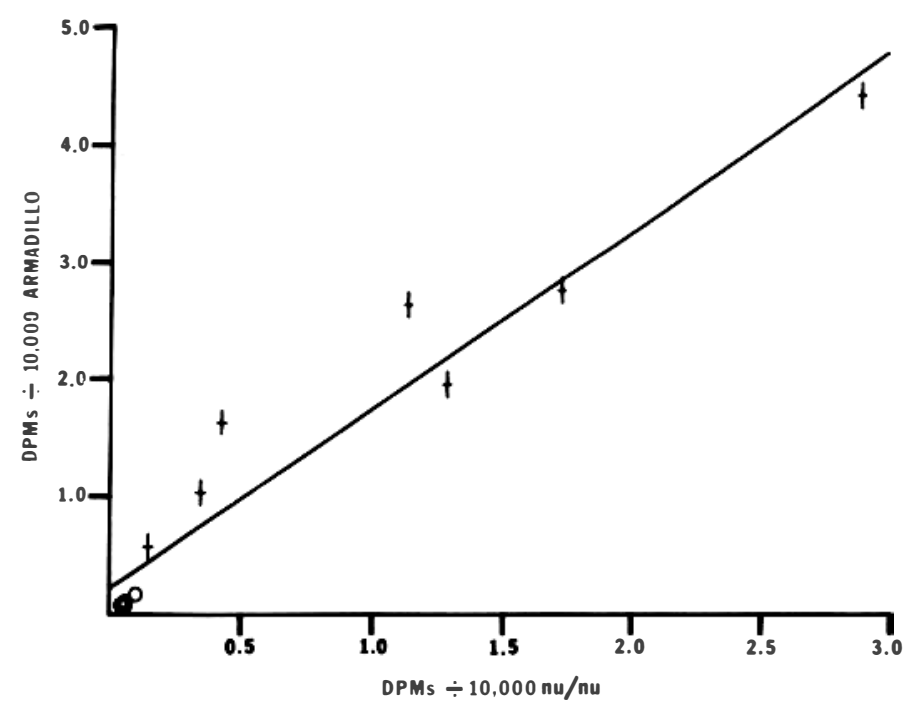

Figure 10. Disintegrations per minute (DPM) ${ }^{3} \mathrm{H}$-thymidine incorporation in 6-day human lymphocyte cultures in response to Dharmendra antigens prepared from armadillo-derived Mycobacterium leprae and acid-fast bacilli harvested from nu/nu mice. $0=$ lepromin-negative subjects with lepromatous leprosy. $+=$ lepromin-positive, normal subjects. 
IDENTIFICATION TESTS OF MYCOBACTERIUM LEPRAE

The acid-fast bacilli recovered from the nude mice behaved like $M$. leprae in lymphocyte blast transformation studies (Figure 10), in their ability to oxidize DOPA, their loss of acid-fastness after pyridine extraction, their inability to grow in 3 mycobacterial culture media at room temperature $\left(23-25^{\circ} \mathrm{C}\right), 33^{\circ} \mathrm{C}$ and $37^{\circ} \mathrm{C}$, and in their characteristic growth pattern in BALB/c mice.

\section{HISTOPATHOLOGY}

In the nude mice, at day 5 , an inflammatory reaction was seen in the left hind foot-pad at the site of the inoculation. Small collections of macrophages were seen in the interstitial tissue around blood vessels and around striated muscle cells. Acid-fast bacilli were seen inside macrophages, striated muscle cells and a few mast cells. No lesions were seen in other organs.

At day 90, there was an increase in the number of macrophages in the left hind foot-pad. Acid-fast bacilli were present inside macrophages and striated muscle cells. All the other organs were normal.

At day 180 , the left hind foot-pad showed a macrophage granuloma situated beneath the epidermis and incorporating several striated muscle bundles and cutaneous nerves. Acid-fast stain showed bacilli inside macrophages, striated muscle cells, perineurial cells, Schwann cells and fibroblasts. Two Kupffer cells in the liver also showed small clumps of bacilli. The other organs did not show any lesions.

At day 272, the granuloma within the left hind foot-pad had ircreased in size. The muscle cells incorporated in the granuloma showed loss of striation and vacuolation of their cytoplasm. Acid-fast stain showed large clumps of bacilli inside macrophages, striated muscle cells and nerves. The Kupffer cells in the liver and the reticuloendothelial cells in the spleen, bone marrow (in the tail bone) and the lungs showed collections of bacilli.

At day 365, the granuloma in the left hind foot-pad had become even larger due to an increase in the number of macrophages replacing normal tissues. Both ears were infiltrated by small aggregates of macrophages in the sub-epithelial tissue. The bone marrow of the tail bone showed a macrophage granuloma. Acid-fast stain revealed bacilli inside macrophages, nerves and the reticuloendothelial cells of the liver, spleen and lungs. In addition, the other 3 foot-pads, nose and sub-mucosa of the jejunum showed a few macrophages containing acid-fast bacilli.

At day 565, there were disseminated lepromatous lesions involving almost all organs. The left hind foot-pad had a massive macrophage granuloma replacing almost all the normal tissues (Figure 11). Acid-fast bacilli were present in macrophages, muscle cells (Figure 12) and nerves (Figure 13). The other 3 foot-pads were also infiltrated by macrophages containing acid-fast bacilli. 


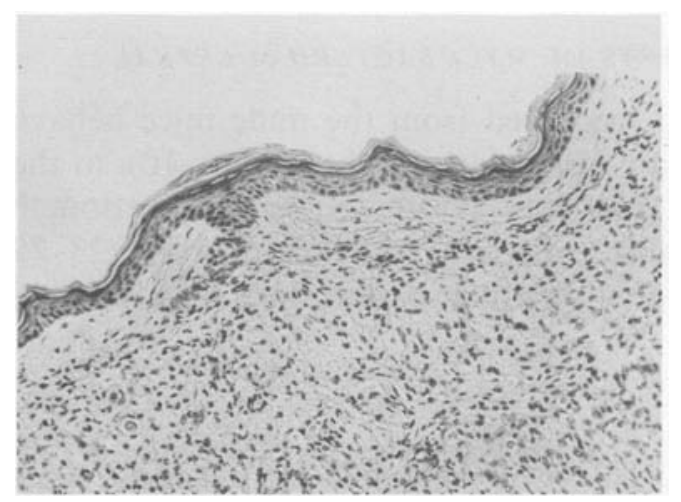

Figure 11. Granuloma in the inoculated hind foot-pad of a nude mouse 565 days after inoculation with $M$ ycobacterium leprae. An atrophic epidermis and a clear area separating the granuloma from the epidermis are clearly seen $(\mathrm{H} \& \mathrm{E} \times 300)$.

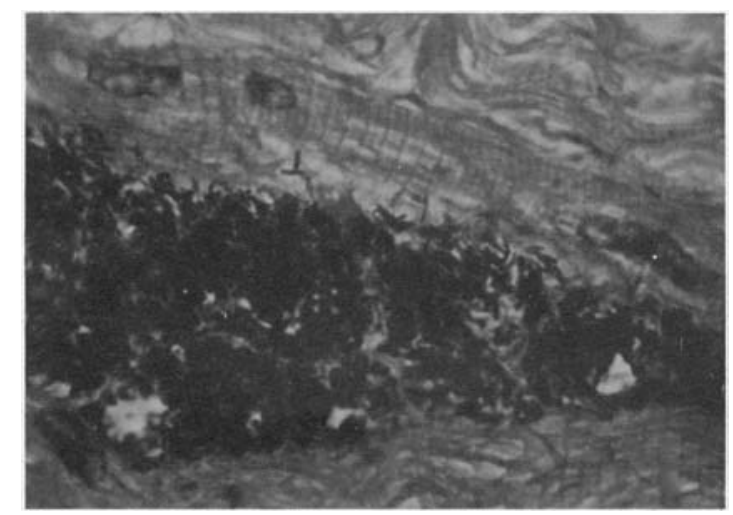

Figure 12. The inoculated hind foot-pad of a nude mouse 565 days after inoculation with Mycobacterium leprae. Striated muscle cells contain a large collection of acid-fast bacilli (modified Fite-Faraco stain, counterstained with Harris' haematoxylin $\times 1100$ ).

Both ears had macrophage granulomas on either side of the cartilage; the outer side seemed to have a larger granuloma than the inner side. Acid-fast stain showed bacilli inside macrophages, perichondrial cells and some cartilage cells.

Skin from the dorsal region, tail and nose had large sub-epithelial granulomas made up of macrophages containing acid-fast bacilli. Besides macrophages, the cells of the hair follicles and the striated muscles in the nose were filled with bacilli.

The organs of the reticuloendothelial system such as the liver, spleen, lymph nodes and bone marrow showed extensive infiltration by macrophages containing acid-fast bacilli (Figure 14). Some liver parenchymal cells also had acid-fast bacilli in their cytoplasm.

The kidneys, adrenals and lungs had collections of macrophages containing 


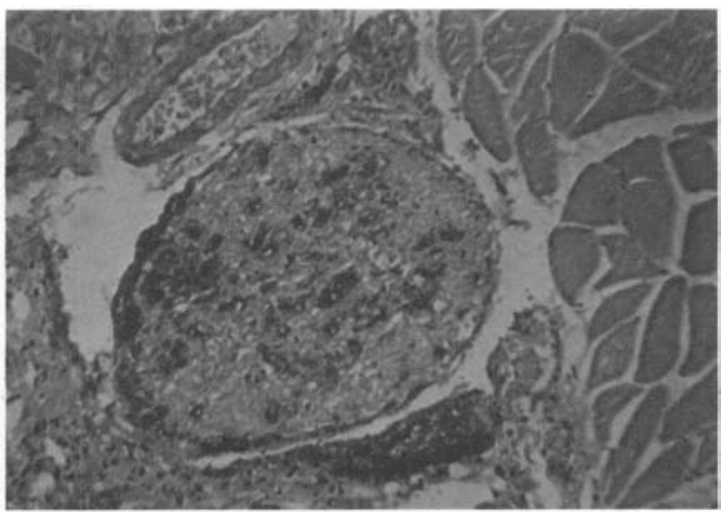

Figure 13. The inoculated hind foot-pad of a nude mouse 565 days after inoculation with Mycobacterium leprae. A nerve bundle with clumps of acid-fast bacilli inside Schwann cells, perineurial cells and macrophages surrounding the nerve (modified Fite-Faraco stain, counterstained with Harris' haematoxylin $\times 300$ ).

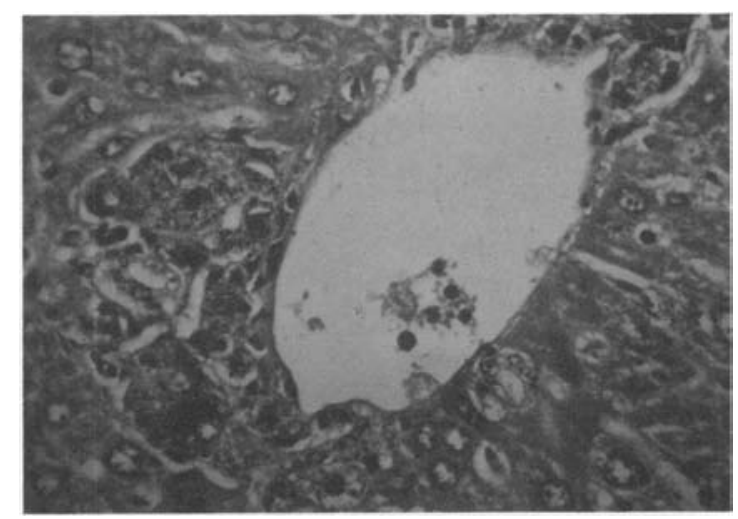

Figure 14. The liver of a nude mouse 565 days after inoculation of the hind foot-pad with Mycobacterium leprae. The portal vein is surrounded by a microgranuloma consisting of macrophages containing acid-fast bacilli (modified Fite-Faraco stain, counterstained with Harris' haematoxylin $\times 900)$.

acid-fast bacilli in the interstitial tissue (Figures 15 and 16). Some lining cells of the distal convoluted tubules of the kidney, the endothelial cells of the glomeruli and alveolar macrophages contained acid-fast bacilli.

The stomach, duodenum, jejunum (Figure 17), and the ileum showed microgranulomas in the mucosa and sub-mucosa. The colon had only submucosal lesions. Many of the macrophages in the granulomas showed acid-fast bacilli. The heart showed acid-fast bacilli inside cardiac muscle cells (Figure 18). The ovarian tissue was extensively replaced by bacilli-filled macrophages. Graafian follicles were also surrounded by bacilli. The brain showed no lesions at any of the time intervals. 


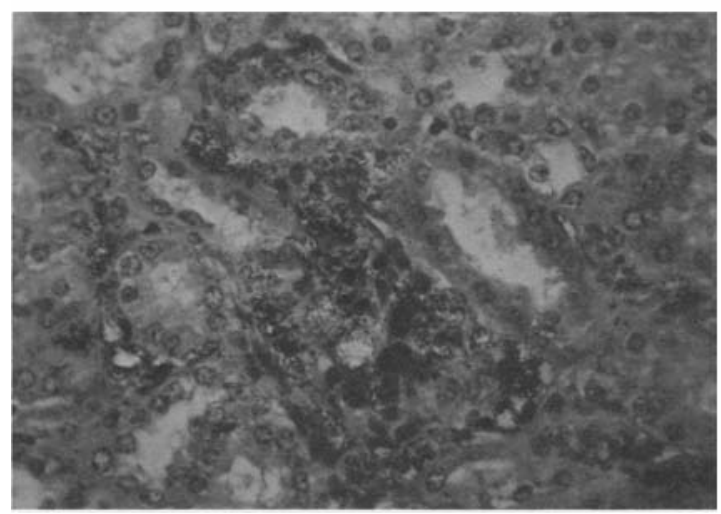

Figure 15. The kidney of a nude mouse 565 days after inoculation in the hind foot-pad with Mycobacterium leprae. The interstitial tissue is invaded by macrophages and acid-fast bacilli are present inside the macrophages and in tubular cells (modified Fite-Faraco stain, counterstained with Harris' haematoxylin $\times 600$ ).

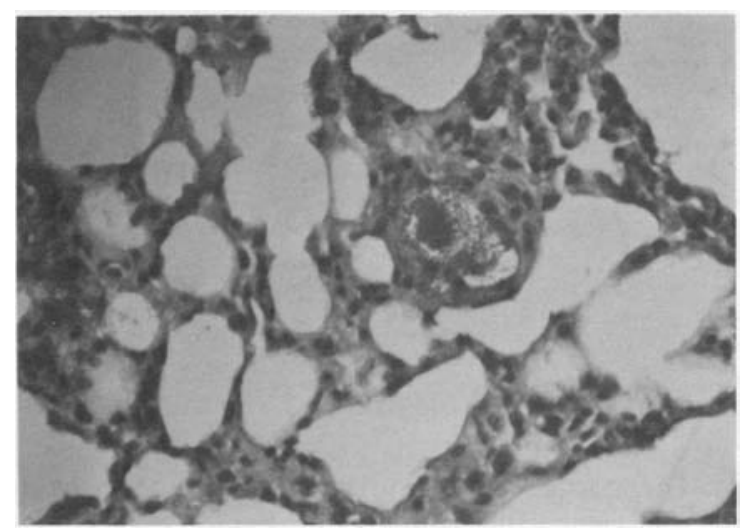

Figure 16. The lung of a nude mouse 565 days after inoculation in the hind foot-pad with Mycobacterium leprae. There is a macrophage granuloma containing acid-fast bacilli in the interstitial tissue (modified Fite-Faraco stain, counterstained with Harris' haematoxylin $\times 600$ ).

\section{ELECTRON MICROSCOPIC STUDY}

The majority of the cells of the nude mice which contained bacilli were identified as macrophages. These were large cells with abundant cytoplasm containing numerous phagosomal vacuoles, a moderate number of mitochondria and numerous finger-like villi at the periphery of their cytoplasm. Most of the 


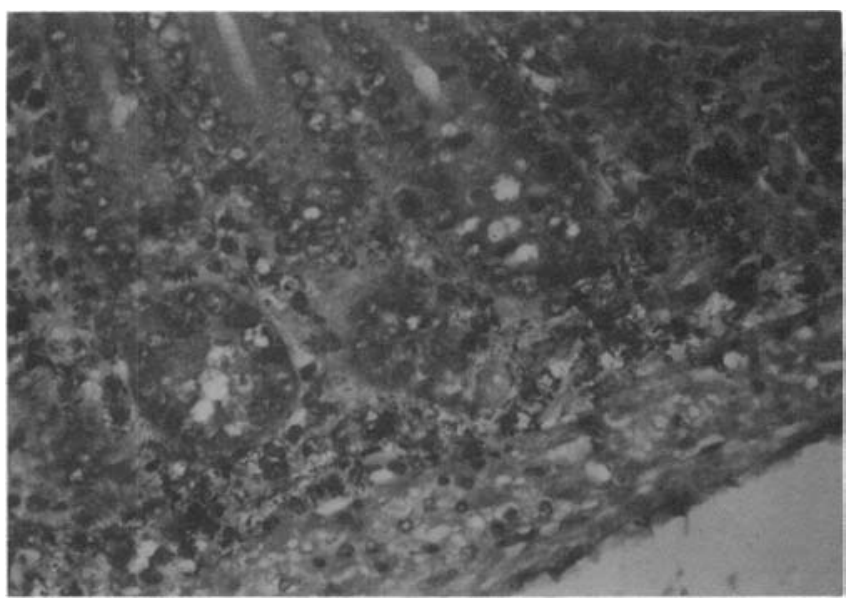

Figure 17. The jejunum of a nude mouse 565 days after inoculation of the hind foot-pad with Mycobacterium leprae. The sub-mucosa is infiltrated by macrophages containing acid-fast bacilli (modified Fite-Faraco stain, counterstained with Harris' haematoxylin $\times 600$ ).

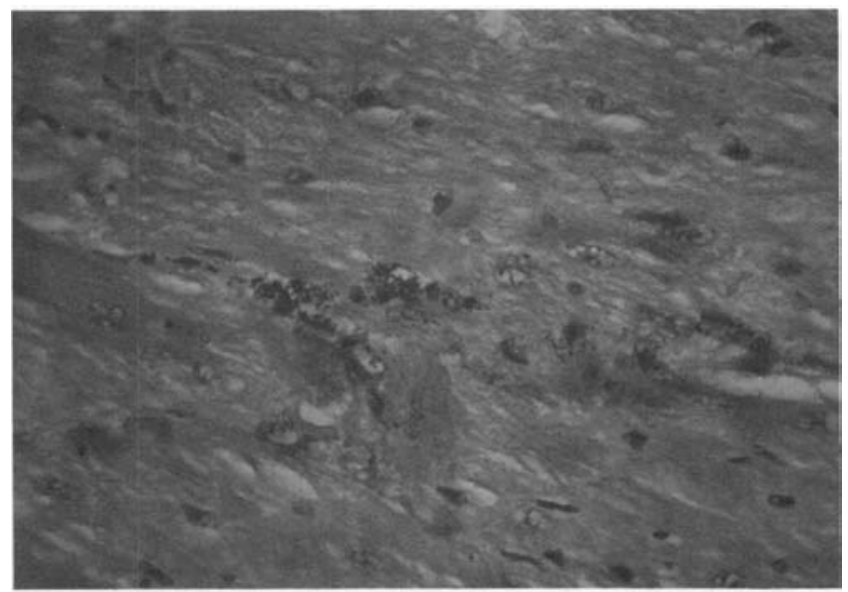

Figure 18. The heart of a nude mouse 565 days after inoculation in the hind foot-pad with Mycobacterium leprae. The cardiac muscle shows intracellular acid-fast organisms (modified Fite-Faraco stain, counterstained with Harris' haematoxylin $\times 600$ ).

phagosomes contained $M$. leprae (Figure 19). Some of the bacilli were seen free in the cytoplasm without a surrounding phagosomal membrane (Figure 20). All of the organisms had a halo of an electron transparent zone (ETZ).

The cutaneous nerve bundles showed bacillary invasion of perineurial cells (Figure 21) and Schwann cells. The cytoplasmic response of these cells to $M$. leprae was the same as that of the macrophages. 


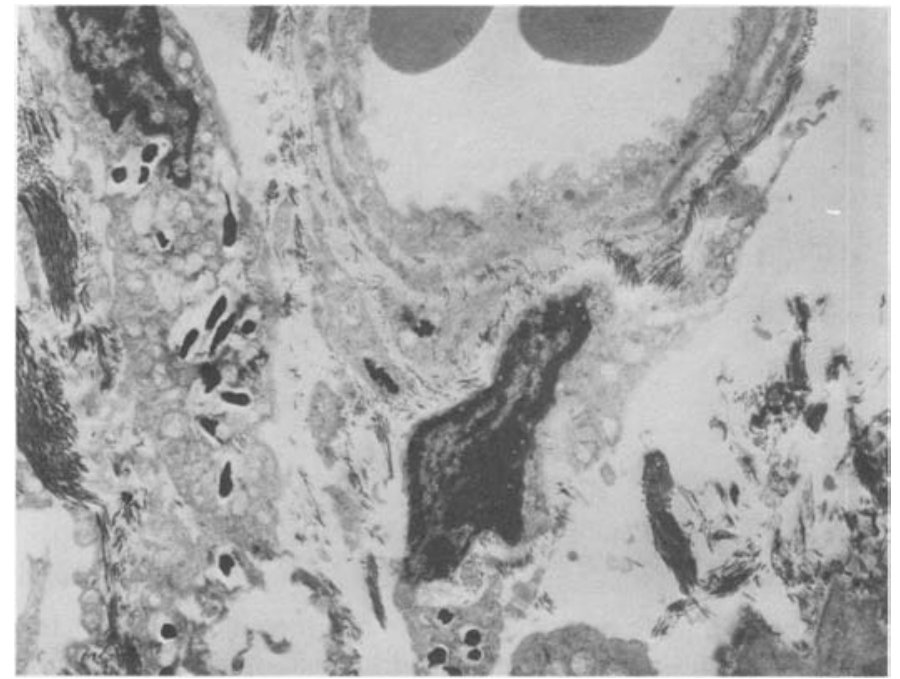

Figure 19. Electron micrograph of the foot-pad of a nude mouse 217 days after inoculation with $1 \times 10^{8}$ Mycobacterium leprae. There is a perivascular collection of macrophages containing numerous $M$. leprae within phagosomal vacuoles. Note the electron transparent zone (ETZ) around most of the bacilli. The macrophages have no basement membrane and the periphery of their cytoplasm shows numerous finger-like villi (original magnification $\times 9000$ ).

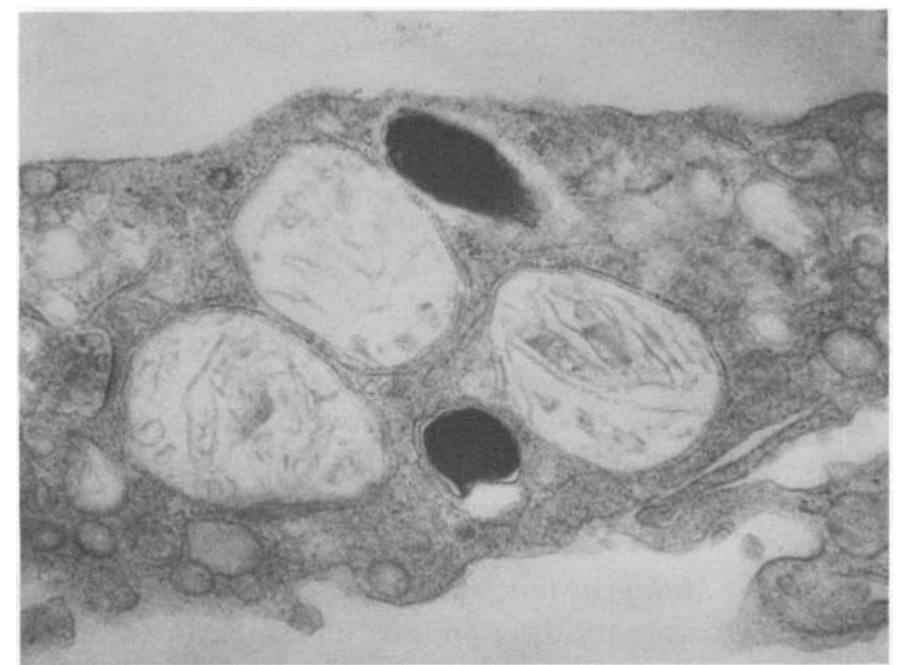

Figure 20. The foot-pad of a nude mouse 217 days after inoculation with $1 \times 10^{8}$ of $M$ ycobacterium leprae. A macrophage with its cytoplasm showing several swollen and degenerating Mitachondria and $2 \mathrm{M}$. leprae. One organism (below) is surrounded by phagosomal membrane, and the other (above) is not surrounded by a phagosomal membrane (original magnification $\times 50,000$ ). 


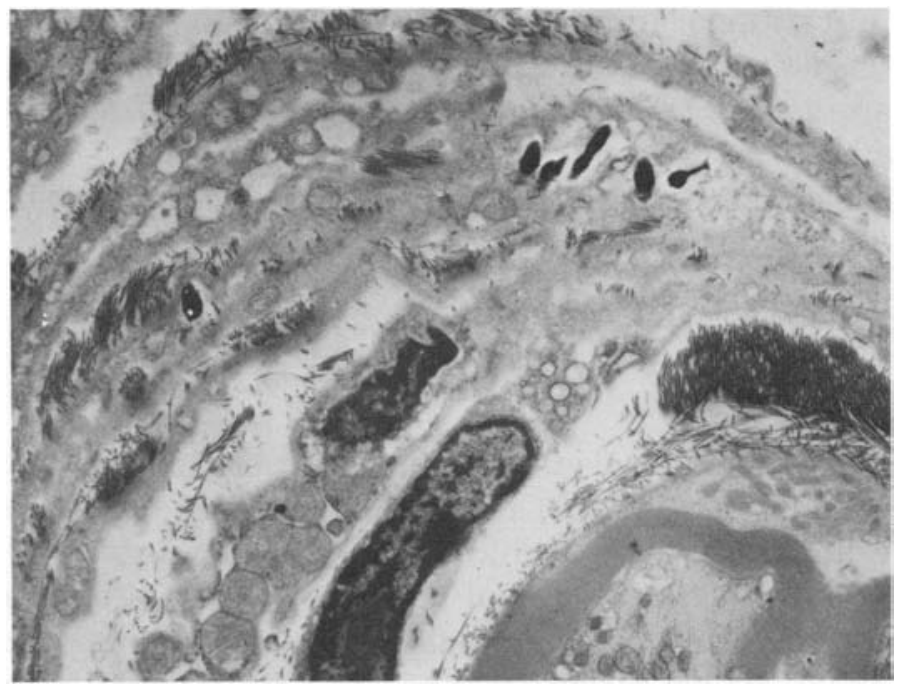

Figure 21. The foot-pad of a nude mouse 217 days after inoculation with $1 \times 10^{8}$ of Mycobacterium leprae. A small cutaneous nerve bundle with its perineurial cells containing several $M$. leprae (original magnification $\times 11,000$ ).

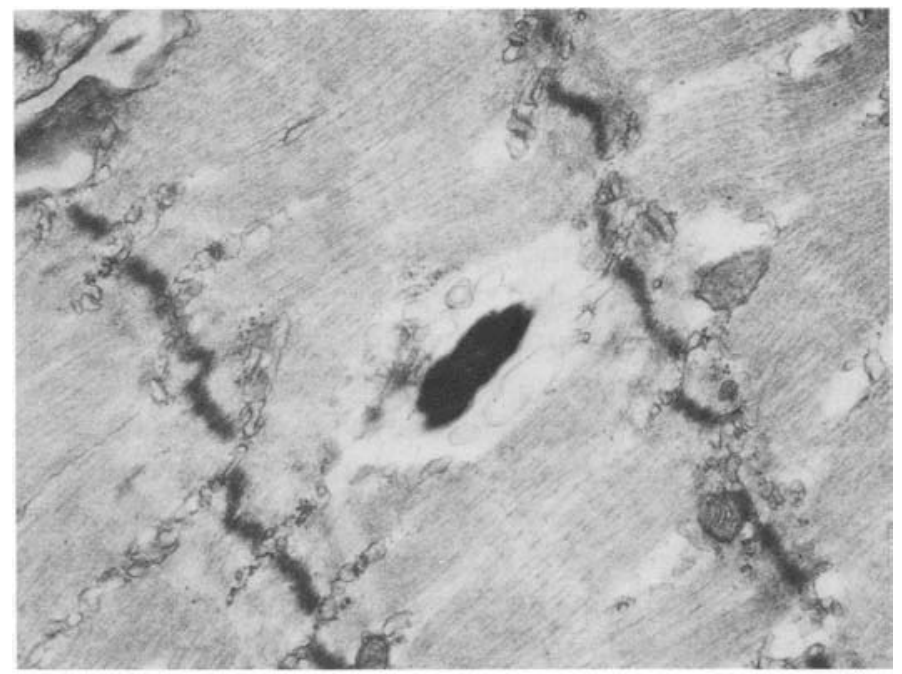

Figure 22. The foot-pad of a nude mouse inoculated 217 days earlier with $1 \times 10^{8}$ Mycobacterium leprae. A striated muscle cell contains an organism in its cytoplasm without a surrounding phagosomal membrane. A few small membrane-bound vesicles are seen in the electron transparent zone $($ ETZ) (original magnification $\times 41,600)$. 
The most interesting feature of this study was the presence of a large number of $M$. leprae inside many of the striated muscle cells. This confirmed the light microscopic appearance (Figure 22). The organisms were found free within the cytoplasm without any phagosomal membrane. The ETZ was clearly seen around the bacilli and there were also aggregates of membrane-bound vesicles producing a foamy change in the cell cytoplasm.

\section{Discussion}

Nude mice were first mentioned in $1962,{ }^{12}$ first described in $1966^{13}$ and were shown to be athymic in $1968 .{ }^{14}$ The trait is inherited as an autosomal recessive. The animals have abnormal keratinization of poorly developed hair follicles, a sulphhydryl group deficiency, ${ }^{13,}{ }^{15}$ and under conventional housing conditions have a short lifespan. Under conventional conditions more than half die before weaning and the maximum survival is approximately 25 weeks of age. ${ }^{13,16}$ On the other hand, although susceptible to a variety of infections, nude mice can be kept in good health for the normal lifespan of a mouse if kept under strictly pathogen-free conditions. Such animals can survive for 2 years or longer ${ }^{15,17}$ and in the first year of life can have a mortality of $1-3 \%{ }^{17}$

Nude mice are highly susceptible to many bacterial, fungal and viral infections. Surprisingly, however, particularly when housed under conventional or specific pathogen-free (but not germ-free) conditions, they showed an enhanced resistance to some microbes, including Candida albicans, Brucella abortus, Pseudomonas aeruginosa, ${ }^{18}$ Listeria monocytogenes, ${ }^{18},{ }^{19}$ Aspergillus fumigatus $^{20}$ and Staphylococcus aureus. ${ }^{19}$ Rao et al. ${ }^{21}$ showed that peritoneal macrophages from conventionally housed nude mice would not support the growth of vaccinia virus in contrast to peritoneal macrophages of nude mice housed under germ-free conditions and of nude mice that had been reconstituted with thymic transplants. They concluded that there are stimuli in a conventional environment which can activate nude mouse macrophages and this activation is not totally dependent on functioning $\mathrm{T}$ lymphocytes. It has been speculated ${ }^{19}$ that fixed-tissue macrophages of conventionally housed nude mice are activated as a direct consequence of their thymic deficiency. This macrophage activation could be due to reticuloendothelial system stimulation by normal gut flora in these animals and could be on the basis of (a) a lack of suppressor $\mathrm{T}$ cells which normally modulate macrophage activation, (b) macrophage activation by direct acting agents such as lipopolysaccharides of Gram-negative organisms, bacterial phospholipids, or agents similar to Corynebacterium parvum; or (c) macrophage activation by lymphokine-like substances produced by stimulated B lymphocytes.

In this regard, it should be noted that the strain of nude mice used in the present study, [(BALB/c An Bom) nu/nu DF] have been described as having a 
caecal flora of Lactobacillus, $\alpha$ and $\gamma$ streptococci, Escherichia coli, Proteus mirabilis, and Micrococcus. It should also be noted that non-T lymphocytemediated resistance to infectious agents can be markedly influenced by the genetic background of the nude mouse..$^{22}$ The present strain of nude mice are from a $\mathrm{BALB} / \mathrm{c}$ background, a strain already known to be relatively susceptible to Mycobacterium leprae.

Nude mice have been utilized in studies of non-leprosy mycobacterial diseases. Nude mice were injected intravenously with the Ravenel strain of $M$. bovis, the BCG strain of $M$. bovis and the Flamingo strain of M. avium. In 12-17-day experiments the nude mice had higher numbers of viable organisms in each instance compared to heterozygote controls. ${ }^{23}$ In a long-term experiment, $2 \cdot 2 \times 10^{6}$ viable BCG were injected intravenously into nude mice and the course of the infection was followed for 175 days. The levels of BCG did not decline in any organ in the nude mice but none died of the BCG infection up to day 175. Up to approximately $10^{7}$ viable BCG were found in the lungs of nude mice at the end of 175 days compared to approximately $10^{3}$ viable organisms in the heterozygote controls. $^{23}$

The animal model of disseminated $M$. leprae in mice, other than nude mice, is the thymectomized, irradiated animal. ${ }^{24}$ Nineteen months after intravenous injection of $3 \times 10^{7} \mathrm{M}$. leprae into these animals, disseminated infections were evident with bacillary yields of $2 \times 10^{9}$ in the nose and ears, $7 \times 10^{8}$ in the foot-pad, $10^{8}$ in the liver, $5 \times 10^{7}$ in the spleen and $10^{7}$ in the lungs, with a total body yield of $1 \cdot 8 \times 10^{10}$ bacilli. Overall, $95 \%$ of the bacilli were found in the foot-pads, ears and nose. Foot-pad yields approaching $10^{9}$ organisms could be obtained 10-16 months after foot-pad inoculation of either $10^{4}$ or $10^{6} \mathrm{M}$. leprae. ${ }^{25} \mathrm{In}$ this model, $M$. leprae appeared to preferentially colonize skeletal muscle fibres and later to involve perineural cells and macrophages. Eventually the histopathology of skin lesions was that of advanced human lepromatous leprosy. ${ }^{26}$

It has been demonstrated that these animals support the growth of $M$. leprae and that bacillary yields were considerably higher than those obtained from conventional mice. Colston \& Hilson ${ }^{2}$ inoculated both hind foot-pads of 30 nude mice with $5 \times 10^{5} \mathrm{M}$. leprae from an untreated lepromatous leprosy patient. Two nude mice survived beyond 160 days, one expiring at day 266 and one at day 322 . There were approximately $10^{8}$ bacilli per foot-pad at day 266 and approximately $10^{9}$ at day 322 . The last surviving animal contained approximately $4.0 \times 10^{5}$ bacilli in its liver, $2.0 \times 10^{5}$ in the spleen, $8.0 \times 10^{4}$ in the nose, $2.0 \times 10^{4}$ in the tail, and $10^{4}$ in each of the forepaws and testes. The acid-fast bacilli were identified as $M$. leprae by the pyridine extraction test and their growth pattern on passage into immunologically intact mice. ${ }^{2}$

Nakamura \& Yogi (private communication) reported the growth of $M$. leprae in nude mice. After foot-pad inoculation of $8.5 \times 10^{3}$ bacilli, yields of up to $2.5 \times 10^{9}$ were obtained 17 months later. Similar yields were obtained after inocula of $1.5 \times 10^{6}$ bacilli per foot-pad. In conventionally reared nude mice from 
various background strains, inoculated with $4.0 \times 10^{6}$ bacilli, yields of $7 \cdot 7 \times 10^{7}$ to $1.7 \times 10^{9}$ bacilli were obtained after 12 months. The bacilli were identified as $M$. leprae by lack of foot-pad swelling 6 months after inoculation into normal or nude mice, by pyridine treatment, and by lack of growth on a modified egg yolk medium.

Kohsaka et al.' initially inoculated 8 nude mice into the hind foot-pad with $10^{4}$ $M$. leprae and reared and maintained the animals in vinyl plastic isolators under specific pathogen-free (SPF) conditions. At 13 months, foot-pad yields of $2 \cdot 6 \times 10^{6}$ bacilli were found and by 17 months all 3 surviving mice had swollen foot-pads and 2 of the 3 had ulcerations at the base of the tail and swelling of the eyelids. The bacilli were identified as $M$. leprae by lack of in vitro growth on Ogawa's egg medium, growth curves in immunologically intact mice, the pyridine extraction test, oxidation of D-dopa and lepromin skin testing. Subsequent work $^{27,} 28$ has shown that foot-pad inocula of $1 \cdot 0-2 \cdot 2 \times 10^{6} \mathrm{M}$. leprae from nude mice passaged into new nude mice provide yields of $3.6 \times 10^{8}$ bacilli per foot-pad after 10 months and that in one experiment $3.6 \times 10^{6}$ bacilli from human biopsy material yielded $1.1 \times 10^{10}$ bacilli in 8 months. ${ }^{27}$ Ten months after foot-pad inoculation of $1 \cdot 0-2 \cdot 2 \times 10^{6}$ bacilli from nude mice passage, dissemination was noted with $3.6 \times 10^{8}$ bacilli in the inoculated foot-pad, approximately $4.0 \times 10^{6}$ in the liver, $4.0 \times 10^{5}$ in the earlobes, $2.0 \times 10^{5}$ in the nose, $2.0 \times 10^{5}$ in the lung, $8.0 \times 10^{4}$ in the tail, $6.0 \times 10^{4}$ in the spleen and $5.0 \times 10^{4}$ in the forepaws. In general, bacillary yields were correlated with lower local temperatures in these sites. ${ }^{27}$ Bacillary yields in the liver were approximately $2.0 \times 10^{6} / \mathrm{g}$ and maximum foot-pad swelling was $2-5 \mathrm{~mm}$ thickness. ${ }^{28}$

The present results show reasonable survival of $M$. leprae-infected nude mice under sterile, laminar flow conditions. Experiments of 12-18 months' duration are not unreasonable. $M$. leprae multiply to 'saturation' levels in inoculated foot-pads of nude mice and thereafter further bacterial multiplication is accompanied by enlargement of the tissue (leproma formation). Dissemination of bacteria from the inoculated foot-pad is relatively slow despite documented bacillemia occurring relatively early. There is a progressive reduction in the Morphological Index in nude mice with time suggesting that non-immune resistance mechanisms play some role in limiting the proliferation of $M$. leprae in this model. Other than the central nervous system, bacteria were eventually found in virtually all tissues examined. Bacilli were found in macrophages both within phagosomes and free in the cytoplasm. All bacilli showed a halo of an electron transparent zone. There were large numbers of $M$. leprae inside many striated muscle cells, the organisms being found free within the cytoplasm without any phagosomal membrane.

Bacilli from sterile (germ-free rather than SPF) nude mice might be particularly useful in cultivation experiments since one would expect them to be free of contamination by other bacteria due to their life-long sterile environment. This model, similar to other models of multi-bacillary leprosy, may prove useful 
in the detection of 'persisters', in the deliberate induction of drug-resistant mutants of $M$. leprae, in chemotherapeutic and immunotherapeutic experiments, and in the production of $M$. leprae in areas without armadillo facilities.

In conjunction with slow-freezing of infected tissues and subsequent storage of the infected tissue at $-80^{\circ} \mathrm{C}$, interesting strains of $M$. leprae can be grown in nude mice and preserved in a viable state for long periods of time. The model lends itself to adoptive transfer experiments using mononuclear cells from $\mathrm{nu} / \mathrm{nu}-\mathrm{BALB} / \mathrm{c}$ heterozygote donors since this combination excludes graft $v s$. host reactions. Because of the immunoincompetence of the homozygous nu/nu animal recipients, host $v s$. graft reactions would also not be expected. Finally, because of the uniform susceptibility of these animals to $M$. leprae, the model has promise as a means of studying the most likely routes of transmission of $M$. leprae.

\section{Acknowledgments}

The authors wish to express their deepest appreciation to Geraldine Black, M J Morales, V Richard and Dr E J Shannon, for their technical assistance and Ms Renée Painter for preparation of the transcript. This study was supported in part by Grant CAR-07-78 from the Division of Hospitals and Clinics, Bureau of Medical Services, United States Public Health Service.

\section{References}

${ }^{1}$ Kohsaka K, Mori T, Ito T. Lepromatoid lesions developed in nude mouse inoculated with Mycobacterium leprae. La Lepro, 1976; 45: 177-87.

2 Colston MJ, Hilson GR. Growth of Mycobacterium leprae and M. marinum in congenitally athymic (nude) mice. Nature, 1976; 262: 736-41.

3 Hastings RC, Chehl SK, Morales MJ, Shannon EJ, Kirchheimer WF. Multiplication of acid-fast bacilli in nude mice inoculated with armadillo derived M. leprae. Int J Lepr, 48 (4): 490-1.

${ }^{4}$ Hastings RC, Chehl SK, Black G, Morales MJ, Shannon EJ, Kirchheimer WF. Growth of $M$. leprae in nude (athymic) mice. In Immunological Aspects of Leprosy, Tuberculosis and Leishmaniasis. Humber David P (ed), Amsterdam-Oxford-Princeton: Excerpta Medica, 1981, pp. 166-76.

${ }^{5}$ Prabhakaran K, Harris EB, Kirchheimer WF. Binding of ${ }^{14} \mathrm{C}$-labelled dopa by Mycobacterium leprae in vitro. Int J Lepr, 1976; 44: 58-64.

${ }^{6}$ Shepard CC. The experimental disease that follows the injection of human leprosy bacilli into footpads of mice. J. exp Med, 1960; 112: 445-54.

7 Shepard CC, McRae DH. A method for counting acid-fast bacteria. Int J Lepr, 1968; 36: 78-82.

8 Prabhakaran K, Harris EB, Kirchheimer WF. Confirmation of the spot test for the identification of Mycobacterium leprae and occurrence of tissue inhibitors of DOPA oxidation. Lepr Rev, 1977; 48: 49-50.

9 McCormick GT, Sanchez RM. Pyridine extractability of acid-fastness from Mycobacterium leprae. Int J Lepr, 1979; 47: 495-9. 


\section{$304 S$ Chehl et al.}

${ }^{10}$ Cochrane RG, Davey TF. Preparation of lepromin. In Leprosy in Theory and Practice. Cochrane RG, Davey TF (eds), Baltimore: The Williams and Wilkins Company, 1964, p. 188.

1 Shannon EJ, Powell MD, Jacobson RR, Hastings RC. Investigations of suppressor mechanisms in clinical leprosy. Dermatol Rev Mex, 1981; 25: 457-68.

12 Isaacson JH, Lattanack BM. Mouse News Lett, 1962; 27: 31.

13 Flanagan SP. 'Nude', a new hairless gene with pleiotrophic effects in the mouse. Genet Res (Camb), 1966; 8: 295-309.

14 Pantelouris EM. Absence of thymus in a mouse mutant. Nature, 1968; 217: 370.

15 Helson C. The nude mouse model. In: Cancer and Chemotherapy, New York, Academic Press, 1980, Vol. I pp 229-245.

16 Wortis HH, Nelson S, Owens JJ. Abnormal development of thymus in 'nude' mice. J Exp Med, 1971; 134: 681-92.

17 Giovanella BC. Experimental chemotherapy of human tumors heterotransplanted in nude mice. Anti Chemo, 1980; 28: 21-7.

18 Johnson WJ, Balish E. Macrophage function in germ-free, athymic (nu/nu) and conventional flora (nu/+) mice. J Reticuloendothel Soc, 1980; 28: 55-66.

19 Nickol AD, Bonventre PF. Anomalous high native resistance of athymic mice to bacterial pathogens. Infect and Immun, 1977; 18: 636-45.

20 Williams DM, Dwight M, Weiner MH, Drutz DJ. Immunologic studies of disseminated infection with Aspergillus fumigatus in the nude mouse. J Infect Disease, 1981; 143: 726-33.

${ }^{21}$ Rao GR, Rawls WE, Perez DYE. Macrophage activation in congenitally athymic mice raised under conventional or germ-free conditions. J Reticuloendothel Soc, 1977; 21: 13-20.

22 Nakamura K, Yogi Y. The nude mouse as an experimental lepromatous model (continued): the NFS/N nude mouse as a new model using the intra-upper tip inoculation method. Int $J$ Lepr, 1982; 50 (4): 585-6.

${ }^{23}$ Ueda K, Yamazaki S, Someya S. Experimental mycobacterial infection in congenitally athymic 'nude' mice. J Reticuloendothel Soc, 1976; 19: 77-90.

${ }^{24}$ Rees RJW. Enhanced susceptibility of thymectomized and irradiated mice to infection with Mycobacterium leprae. Nature, 1966; 21: 657-8.

${ }^{25}$ Rees RJW, Waters MFR, Weddell AGM, Palmer E. Experimental lepromatous leprosy. Nature, 1967; 215: 599-602.

26 Rees RJW, Weddell AGM. Experimental models for studying leprosy. Ann N.Y. Acad Sci, 1968; 154: 214-36.

${ }^{27}$ Kohsaka K, Mori T, Ito T. Nude mouse for research in leprosy. Int J Lepr, 1978; 46: 121-2.

${ }^{28}$ Kohsaka K, Yoneda K, Makino M, Mori T, Ito T. Experimental leprosy with nude mice. Japan J Lepr, 1979; 48: 37. 